Document downloaded from:

http://hdl.handle.net/10251/60196

This paper must be cited as:

Mas Verdú, F.; Ribeiro Soriano, D.; Roig Tierno, H. (2015). Firm survival: The role of incubators and business characteristics. Journal of Business Research. 68(4):793-796. doi:10.1016/j.jbusres.2014.11.030.

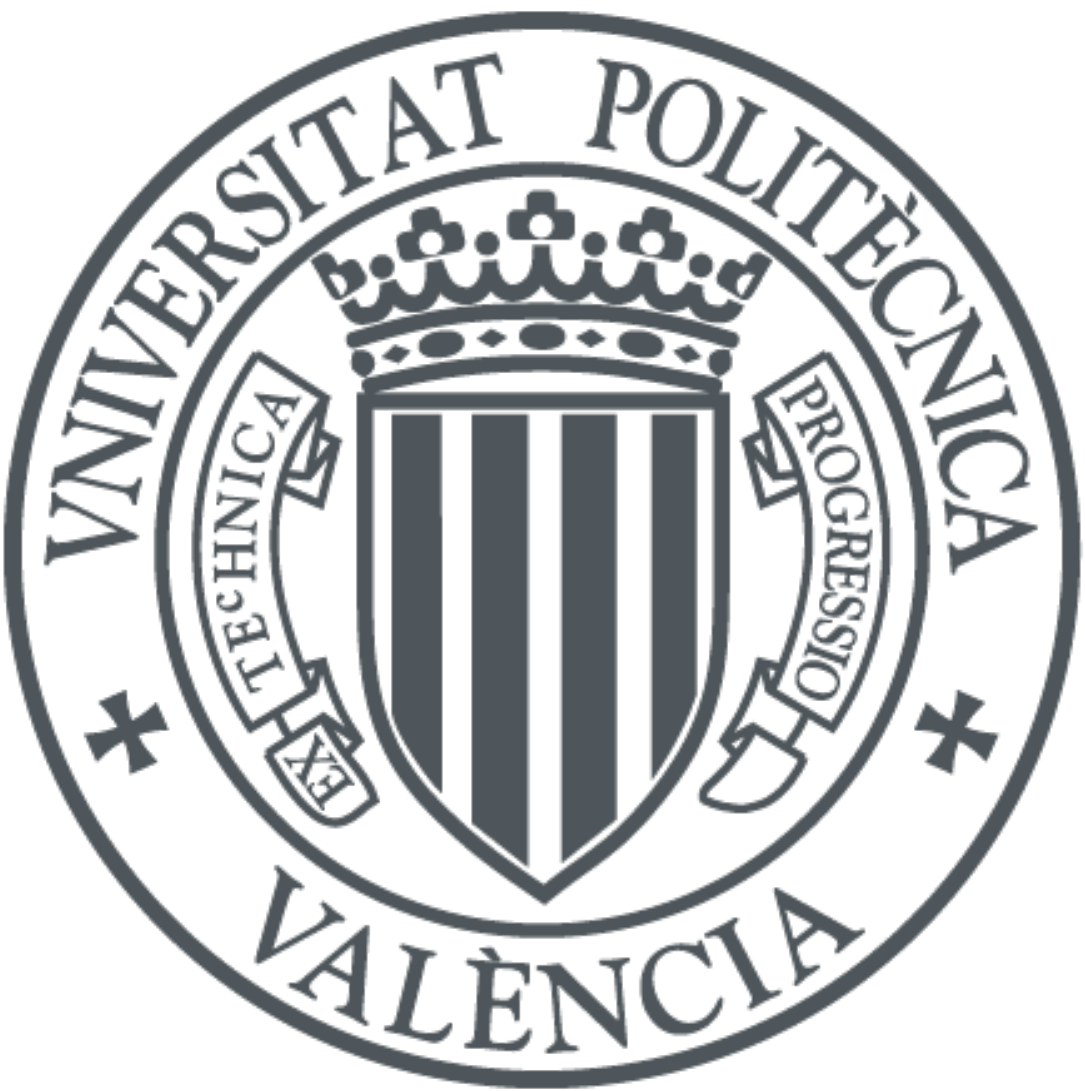

The final publication is available at

http://dx.doi.org/10.1016/j.jbusres.2014.11.030

Copyright Elsevier

Additional Information 


\title{
Firm survival: The role of incubators and business characteristics
}

\author{
Francisco Mas-Verdú, Universitat Politècnica de València \\ Domingo Ribeiro-Soriano, Universitat de València \\ Norat Roig-Tierno, Universidad Europea de Valencia
}

March 2014

\begin{abstract}
Please send correspondence to: Norat Roig-Tierno, Universidad Europea de
Valencia, C/General Elio, nº 2, 8 y 10, 46010 SPAIN. E.mail address:

honorat.roig@uem.es, noratroig@gmail.com. Domingo Ribeiro-Soriano
\end{abstract}

Universitat de València. E-mail address: domingo.ribeiro@uv.es Francisco Mas-

Verdú. Universitat Politècnica de València. E-mail address:

fmas@upvnet.upv.es

The main objective of this research is to analyze the impact of business incubatorson the survival of their associated firms. Using a configurational comparative method, the fuzzy-set qualitative comparative analysis (fs/QCA), it also examines whether the degree of business innovation, size, sector of activity and export activity affect firm survival. One of the most notable conclusions from this analysis is that the survival of a firm is related with at least some of the following characteristics: the firm must be technology-based, its productive focus is on goods (rather than on services), or that it is located within the specific environment of A business incubator.

Keywords: incubators, firm survival, fs/QCA. 


\section{INTRODUCTION}

Interest from social and economic actors in the creation of new business has grown steadily over the last 30 years. Business incubators are one of the instruments designed to achieve increased regional development, thereby fostering the creation of new firms and employment (Phan, Siegel and Wright, 2005 NUEVAS REFERENCIAS). The objective of a business incubator is to create and develop companies or accelerate the creation of successful firms (Bruneel, Ratinho, Clarysse and Groen, 2012).

The objective of this study is to analyze the efficiency and impact of incubators on the survival rate of firms realted with them or that function under their influence. The study also identifies whether other factors, such as the degree of business innovation, firm size, the sector of activity and amount of export activity affect firm survival.

To comply with these objectives, we use a configurational comparative method, the fs/QCA (Ragin, 1987). This method allows researchers to overcome one of the main limitations of traditional probability-based statistical techniques - the need for largesized samples - without limiting the study to certain cases, thus enabling the generalization of conclusions or implications to a larger population.

The structure of the article is as follows. The next section contains the theoretical framework, setting out the different theories developed in the literature that refer to the survival of firms within an incubator framework. The third section describes the study methodology and presents the results, ending with the main conclusions of the study

\section{FIRM SURVIVAL}

Existing literature that analyzes firm survival (Box, 2008; Holmes, 2010; Carr, Haggard, Hmieleski, and Zahra, 2010) underwrite the importance of the following 
conditions are keys: firm size, sector, export activity and innovation intensity. This research examines these variables, together with the influence of incubators, to analyze firm survival.

\section{The impact of business incubators on firm survival}

The main objective of an incubator is to 'produce' successful firms that will leave the incubator once they are independent and financially viable - the moment when they 'graduate'. Moreover, this primary objective of incubators is complemented by a more specific one: to stimulate innovation and regional development. Therefore, one function of incubators is to assist future entrepreneurs when they initiate their business activities, providing them with basic infrastructures, financial resources and different types of services and information for startups (Alonso et al., 2008). Incubators thus act as catalysts of new entrepreneurial experiences (Maroto Sanchez and García Tabuenca, 2004).

Although the main objective of an incubator is new firm creation, literature on this topic places particular emphasis on the success or survival of these firms once they graduate in terms of the impact incubators can have on firm survival. The study by Schwartz (2013) presents a detailed review of previously published research on the topic. Schwartz firstly examines a series of 11 studies that analyze this impact, and goes on to provide a new evaluation of the impact on 371 firms over a 10-year period, contributing methodological improvements in terms of group control.

However, few studies have systematically studied the effectiveness or the impact of incubators on the survival of firms associated with the incubator itself (Phan et al., 2005) Certain authors argue that the problem lies in the lack of an adequate theoretical framework for systematically analyzing the impact of incubators, and go as far as to call 
the topic a black box (Hackett and Dilts 2004, 2008), while others propose an in-depth analysis on the evolution of the value proposition in terms of business and innovation provided by incubators in order to adequately assess the impact on their associated firms (Bruneel et al., 2012).

Hypothesis 1: Firms located within an incubator have a greater chance of survival than non-associated firms.

\section{Technology-based firms and survival}

Emphasis of entrepreneurship policy lies not only on the creation of firms at a general level, but on the creation of technology-based firms (Schwartz, 2013). Various authors (Cockburn and Wagner, 2007; Buddelmeyer et al., 2009) have examined the impact of innovation on firm survival. In almost all cases, such studies propose the existence of a positive relation between survival and the level of innovation. Specifically in case of technology-based some characteristics (Nerkar and Shane, 2003; Cockburn and Wagner 2007) constitute a basic element of competitive advantage. So technology-based firms therefore constitute businesses that, due to their innovative characteristics, have a high growth and survival potential (Motohashi , 2005).

Hypothesis 2: Technology-based firms have a higher chance of survival than non-technology-based businesses.

(ESTA ES LA BUENA) Firms using innovation have a higher chance of survival

\section{The influence on survival of firm size and sector of activity}


In terms of the size of the business, the question is whether firm size at the start of the life cycle has any effect on subsequent survival (Agarwal and Audretsch, 2001). Some researchers have showed that firms that initiate their activity with a larger size are more likely to grow than firms that start small (Fritsch, Brixy and Falck, 2006). As there is a minimum size below which firms are, in most cases, doomed to failure In other words, firm size at the moment of initiating activity has a positive relation with market permanence (Audretsch et al., 2000)

Hypothesis 3: The chances of firm survival increase in accordance with the size of the firm.

\section{(DEFINIR “DYNAMIC SECTORS”)}

According to Dunne et al. (1989), the sector a firm belongs to is one of the explanatory variables of the likelihood of survival. Therefore, firms that begin their activity in sectors that are undergoing a period of growth have a greater chance of growing, and therefore of surviving. Some researchers (Mata et al., 1995) argue that, in some sectors, new firms have a greater capacity to find a place in the market and remain there. In short, the rate of survival appears to be linked with the level of technology of each sector, so that firms involved in activities that are more innovation intensive are in a better position to maintain their market position over time (Cefis and Marsili, 2005).

Hypothesis 4. The a sector is where a firm is active, impact the likelihood of the firm surviving in the mid-term.

\section{The influence of export activity on firm survival}


There are substantial differences between firms that export and those that do not (Ali, 2010). Bearing in mind the pressures and complexities that come with international competition (Pearce and Robbins, 2008), export firms tend to have particular characteristics (greater productivity and efficiency, a higher degree of innovation, etc.) that increase their survival potential in comparison to non-export firms (Helpman, 2006; Salomon and Shaver, 2005). So internationalization has a favorable impact on growth and firm survival. (Sapienza et al., 2006; Olivares and Suárez, 2007)

Hypothesis 5. The more a firm exports, the more it is likely to survive.

\section{(MODIFICAR LA HYPOTHESIS)}

\section{Research}

\section{Data}

Data on a sample of 47 firms were collected in 2009 using a survey distributed among to CEOs and managing directors. These firms are located within the environment of the European Business and Innovation Centre of Elche (Alicante, Spain). All firms are geographically located within a kilometer of the incubators, and therefore have the chance to enjoy support from the incubator. Out of these 47 firms, 30 of them continue to be active in 2014 and 17 are no longer going concerns. With regard to the use of the services of the incubator, 26 have received support from the incubator whilst 21 have not. Finally, one of the specificities of the sample is the fact that, in terms of size, firms are either micro or small-sized (as there were no large or medium-sized businesses in the sample due to the characteristics of most businesses in the region).

The data used for this study are adequate for the purposes of this research for a number of reasons. Data originate from the autonomous region of the Comunitat Valenciana, a region located in the south east of Spain. The economic base of the region has broadened with the addition of other productive activities (Belso, 2013a). In this sense, 
the Comunitat Valenciana represents a suitable case for analyzing the role of incubators. Some studies have looked to reflect the importance of the role of the promotion of business activities in the region (Belso, et al. 2013, b). The firms were selected from the files of a directory created jointly by the authors and the Valencia Institute for Small and Medium-sized Enterprise (IMPIVA), a public body pertaining to the regional government which devotes its efforts to the promotion of innovation among SMEs.

\section{Method}

Certain fields, such as organizational change management, HRM or the resource-based view (RBV) employ the configurational comparative method to complete insufficient statistical analyses from prior studies (Fiss, 2007; Grandori and Furnari, 2008; Pajunen, 2008; Schneider, Schulze-Bentrop, and Paunescu, 2009; Greckhamer, 2011; Hsu, Woodside, and Marshall, 2013; Woodside, 2013). A configurational comparative method assumes complex causality - a condition or combination of minimum necessary and/or sufficient conditions for a particular outcome-and nonlinear relationships where, "variables found to be causally related in one configuration may be unrelated or even inversely related in another" (Meyer et al., 1993: 1178). Configurational analysis underlines the concept of equifinality, and addresses configurations as varying case types. It refers to scenarios where, "a system can reach the same final state, from different initial conditions and by a variety of different [or multiple] paths" (Katz and Kahn, 1978, p. 30).

Qualitative comparative analysis functions by progressing through several steps. The first step uses measures to construct a truth table with $2 \mathrm{k}$ rows, where $\mathrm{k}$ is the number of causal conditions used in the analysis. Stage two reduces the the number of rows. Ragin (2006) recommends a minimum consistency of 0.75. Establishing the necessary conditions should focus attention on cases that show the outcome, as cases where the 
outcome is not present are irrelevant, and thus should be omitted when testing hypotheses. During the third stage of analysis, following a review of the truth table, the algorithm simplifies combinations and minimizes. The researcher must then determine what to do with the logical remainders. There are three potential solutions: The first is a parsimonious solution that involves all simplifying assumptions regardless or not of whether they are based on easy or difficult counterfactuals. The second is an intermediate solution that merely involves simplifying assumptions based on easy counterfactuals. The complex solution includes neither easy nor difficult counterfactuals.

The notion of whether causal conditions belong to core or peripheral configurations relates to these parsimonious and intermediate solutions: core conditions form a part of both parsimonious and intermediate solutions, and peripheral conditions are eliminated in the parsimonious solution and thus only appear in the intermediate solution.

\section{Findings}

We present the main results from this study in two different analyses. The first analysis aims to explain which conditions lead firms to the outcome, survival, and a second block analyzes the main conditions that lead to firm mortality or absence of the outcome.

The models for analysis are as follows:

$$
\begin{gathered}
\text { surviv }=f(\text { size, ebt, sector, } \text { export, ebic }) \\
\sim \text { surviv }=f(\text { size }, \text { ebt, sector }, \text { export, ebic })
\end{gathered}
$$


where the symbol $(\sim)$ represents the negation of the characteristic, in this case $\sim$ surviv, that is to say, the firm did not manage to survive for the whole of the period 2009-2014. The outcome and conditions correspond to the description and codification that appear in table 2. The outcome is therefore a dichotomous one that shows survival, and distinguishes between firms that are currently active since 2009 .

The conditions are firm size, exports, sector, the degree of innovation and the use of the EBIC. We measure: A) Firm size as a fuzzy-set condition in accordance with the number of employees, classifying businesses into microfirms (close to 0) and small firms (close to 1), bearing in mind the characteristics of the sample mentioned above. B) Export activity is a dichotomous condition, which establishes whether the firm exports goods/services (coding a firm as 1 , fully in this set) or not (coding a firm as 0 , out of the set). C) Sector of competition: dichotomous condition distinguishing between the service sector and others. D) The degree of innovation is a condition that distinguishes technology-based firms (coding a firm as 1, fully in this set) from non-tech firms (coding a firm as 0, out of the set). E) Use of the EBIC is a dichotomous condition that establishes which firms use the services of the EBIC (coding a firm as 1, fully in this set) and those that do not (coding a firm as 0 , out of the set).

\section{Table 2. Insert here.}

Table 3 shows the analysis of independent necessary conditions for the outcome: firm survival. The results indicate that, independently, the conditions do not lead to the survival of the firms in the study, either in terms of need or sufficiency.

Table 3. Insert here.

However, the fs/QCA analysis shows how the combination of several of these conditions is necessary and/or sufficient for firm survival. 
Table 4 presents the results of the intermediate solution derived from the fs/QCA analysis. This solution minimizes the combination, assuming that the conditions of export activity and use of the EBIC lead to firm survival.

Table 4. Insert here.

The results of the analysis lead to the following conclusions: firstly, analysis consistency is high (0.824), which indicates a sufficient relation between firm survival and some of the conditions. General coverage of the model is 0.793 , that is to say, the model explains more than $79 \%$ of the cases that survived.

Now, we examine each of the solutions and configurations from the analysis that appear in table 4. All of the configurations are:

$$
\text { (1) size*ebt (coverage: 0.24, consistency: 0.94) }
$$

Interpretation: in order for a business to survive, it is enough for it to be a small-sized technology-based firm.

(2) size* sector (coverage: 0.48 , consistency: 0.80 )

Interpretation: being a small firm in the industrial district analyzed here that is oriented towards product manufacturing is sufficient to explain survival.

(3) size *ebic (coverage: 0.33, consistency: 0.90)

Interpretation: use of the EBIC on the part of small firms is a necessary condition for ensuring firm survival in this productive environment.

$$
\text { (4) } \sim e b *^{*} \text { sector*ebic (coverage: 0.26, consistency: 0.80) }
$$

Interpretation: innovative firms that use the EBIC and are oriented towards productive sectors possess sufficient characteristics to ensure their survival.

Ragin (2008) recommends that the consistency threshold be set to at least 0.8 . So all the configurations are good for our research. 
Following the interpretation of each of the intermediate solutions resulting from the fs/QCA analysis, we can now proceed with the simplifications of the Boolean logic in order to attempt to synthesize the main results of the study.

Causal combinations (1) to (3) enable us to make the following statement:

$$
\text { size* (ebt+sector+ebic) }
$$

This expression shows that a minimum size with regard to productive structure conditions the survival of a firm in the region analyzed, and the firm must be technology-based or oriented towards goods, or be associated with the EBICs.

Causal combinations (3) and (4) yield the following expression:

$$
\text { ebic* }[\text { size }+(\sim e b t * \text { sector })]
$$

This expression contrasts the indications of the previous paragraph; afirm that participates in and makes use of the activities that EBICs provide to their associated firms and that has a minimum productive structure or whose orientation is towards products but is not a technology-based firm can survive.

Finally, the second analysis uses an identical study but contrasts the non-survival of firms (as opposed to survival). Table 5 shows the results of the analysis.

\section{Tabla 5. Insert here.}

Using the same procedure as in the previous section, the analysis points to several conclusions. It firstly confirms the hypothesis that firms need to be of a minimum size in order to survive in the environment analyzed here, confirmed in all the configurations except for one, which the authors disregard as the coverage is extremely low (less than $5 \%$, that is to say, just one case - the fifth causal configuration in table 5). Therefore, firms stand a high chance of not surviving if they are microfirms (as configurations 1 and 4 show). Secondly, the analysis contrasts the hypothesis that firms in the area not 
using the EBIC run a higher risk of mortality (as causal configurations 1, 2 and 5 appear to indicate). The use of EBICs by firms therefore raises their chances of survival.

\section{Discussion}

The objective of this study is to examine the effectiveness of the use of a particular type of incubator: the European Business and Innovation Centers (EBICs) on firm survival, along with other conditions such as the degree of innovation, firm size, sector of activity, and export activity. The study contains a review of the most recent relevant literature on these variables and use of the fs/QCA (Ragin, 1987) in order to observe the combinations of motivations that lie behind firm survival (and non-survival) in the region under analysis.

The analysis draws a variety of conclusions with regard to the survival of businesses: firm survival is conditioned by a minimum size in terms of productive structure and must also comply with certain other characteristics: the firm must be technology-based or have a productive orientation towards goods or use the services of an EBIC.

This study is not without certain limitations, which could represent further lines of research. The study only addresses a particular type of business incubation center within a specific region. Thus, future research could examine, and even compare, different types or models of business incubation centers. 


\section{References}

Aernoudt, R. (2004). Incubators: Tool for entrepreneurship? Small Business Economics, 23(2), 127-135.

Agarwal, R., \& Audretsch, D. B. (2001). Does entry size matter? The impact of the life cycle and technology on firm survival. The Journal of Industrial Economics, 49(1), 2143.

Ali, M. Y. (2010). Barriers to export and export promotion programs: Insights from SME managers. Queensland: Queensland University of Technology.

Audretsch, D., Houweling, P., \& Thurik, R. (2000). Firm survival in the Netherlands, Review of Industrial Organization, 16, 1-11.

Belso Martínez, J. A Molina-Morales, F. X., \& Mas-Verdu, F. (2013a). Perceived usefulness of innovation programs for high-tech and low-tech firms. Management Decision, 51(6).1190 - 1206

Belso Martínez, J. A. Molina-Morales, F. X., \& Mas-Verdu, F. (2013b). Combining effects of internal resources, entrepreneur and public and private KIS on new firm's size. Journal of Business Research, 66, 2079-2089

Box, M. (2008). The death of firms: Exploring the effects of environment and birth cohort on firm survival in Sweden. Small Business Economics, 31(4), 379 - 393.

Bruneel, J., Ratinho, T. F., Clarysse, B., \& Groen, A. J. (2012). The evolution of business incubators: Comparing demand and supply of business incubation services across different incubator generations. Technovation, 32(2), 110 - 121.

Buddelmeyer, H., Jensen, P.H., \& Webster, E. (2009). Innovation and the determinants of company survival. Oxford: Oxford University Press

Carr J. C., Haggard, K. S, Hmieleski, K. M., \& Zahra, S.A. (2010). A study of the moderating effects of firm age at internationalization on firm survival and short-term growth. Strategic Entrepreneurship Journal, 4(2), 183 - 192.

Cefis, E., \& Marsili, O. (2005). A matter of life and death: Innovation and firm survival. Industrial and Corporate Change, 14(6), 1167 - 1192.

Cockburn, I. M., \& Wagner, S. (2007). Patents and the survival of internet-related IPOs. Cambridge, MA: National Bureau of Economic Research.

Dunne, T., Roberts, M., \& Samuelson, L. (1989). The growth and failure of U.S. manufacturing plants. Quarterly Journal of Economics, 104(4), 671 - 698. 
Esteve-Pérez \& Mañez-Castillejo, J. A. (2008). The resource-based theory of the firm and firm survival. Small Business Economics, 30(3), 231 - 249.

Ferguson, R., \& Olofsson, C. (2004). Science parks and the development of NTBFslocation, survival and growth. The Journal of Technology Transfer, 29(1), 5-17.

Fiss, P. C. (2007). A set-theoretic approach to organizational configurations. Academy of Management Review, 32(4), 1180-1198.

Fiss, P. C. (2011). Building better causal theories: A fuzzy set approach to typologies in organization research. Academy of Management Journal, 54(2), 393-420.

Fritsch, M., Brixy, U., \& Falck, O. (2006). The effect of industry, region, and time on new business survival-A multi-dimensional analysis. Review of Industrial Organization, 28(3), 285-306.

Greckhamer, T. (2011). Cross-cultural differences in compensation level and inequality across occupations: A set-theoretic analysis. Organization Studies, 32(1), 85-115.

Grandori, A., \& Furnari, S. (2008). A chemistry of organizations: Combinatory analysis and design. Organization Studies, 29, 459-485.

Hackett, S. M., \& Dilts, D. M. (2008). Inside the black box of business incubation: Study B-scale assessment, model refinement, and incubation outcomes. Journal of Technology Transfer, 33, 439-471.

Hackett, S., \& Dilts, D. (2004). A systematic review of business incubation research. Journal of Technology Transfer, 29(1), 55-82.

Helpman, E. (2006). Trade, FDI, and the Organizations of Firms. Journal of Economic Literature, vol. XLIV, September, 589-630.

Holmes, P., Hunt, A., \& Stone, I (2010). An analysis of new firm survival using a hazard function.. Applied Economics, 42(2), 185-195.

Hsu, S.-Y., Woodside, A. G., \& Marshall, R. (2013). Critical tests of multiple theories of culture's consequences: Comparing the uselfulness of models by Hofstede, Inglehart and Baker, Schwartz, Steenkamp, as well as GDP and distance, for explaining overseas tourism behavior. Journal of Travel Research, 52(6), 679-704.

Katz, D., \& Kahn, R.L. (1978). The social psychology of organizations (2nd ed.). New York: Wiley.

Mata, J., Portugal, P., \& Guimaraes, P. (1995). The survival of new plants: Start-up conditions and post-entry evolution. International Journal of Industrial Organization, $13,459-481$. 
Meyer, A. D., Tsui, A. S., \& Hinings, C. R. (1993). Configurational approaches to organizational analysis. Academy of Management Journal, 36, 1175-1195.

Motohashi, K. (2005). University-industry collaborations in Japan: The role of new technology-based firms in transforming the national innovation system. Research Policy, 34(5), 583-594.

Nerkar, A., \& Shane, S. (2003). When do start-ups that exploit patented academic knowledge survive? International Journal of Industrial Organization, 21(9), 1391- 1410 .

Olivares, A., \& Suárez, S. (2007). The export development process of Spanish manufacturing firms: An application of survival analysis. Revista Europea de Dirección y Economía de la Empresa, 16(1), 89 - 98.

Pajunen, K. (2008). Institutions and inflows of foreign direct investment: A fuzzy-set analysis. Journal of International Business Studies, 39, 652-669.

Peña, I. (2004). Business incubation centers and new firm growth in the Basque Country. Small Business Economics, 22(3), 223-236.

Phan, P., Siegel, D., \& Wright, M. (2005). Science parks and incubators: Observations, synthesis and future research. Journal of Business Venturing, 20(2), 165-182.

Ragin, C. C. (1987). The comparative method. Moving beyond qualitative and quantitative strategies. Berkeley: University of California Press.

Ragin, C. C. (2000). Fuzzy-set social science. Chicago: University of Chicago Press.

Ragin, C. C. (2006). How to lure analytic social science out of the doldrums: Some lessons from comparative research. International Sociology, 21(5), 633-646.

Ragin, C. C. (2008). Redesigning social inquiry: Fuzzy sets and beyond. Chicago: University of Chicago Press.

Rothaermel, F., \& Thursby, M. (2005a). Incubator firm failure or graduation? The role of university linkages. Research Policy, 34(7), 1076-1090.

Salomon, R. M., \& Shaver, J. M. (2005). Learning by exporting: New insights from examining firm innovation. Journal of Economics and Management Strategy, 14(2), $431-46$

Sapienza, H. J., Autio, E., George, G., \& Zahra, S.A (2006). Capabilities perspective on the effects of early internationalization on firm survival and growth. Academy of Management Review, 31(4), 914-933. 
Schneider, M. R., Schulze-Bentrop, C., \& Paunescu, M. (2009). Mapping the institutional capital of high-tech firms: A fuzzy-set analysis of capitalist variety and export performance. Journal of International Business Studies, 41,246-266.

SCHWARTZ 2013

Sutton, J. (1996). Technology and market structure. European Economic Review, 40(3), 511-530.

Sherman, H., \& Chappell, D. S. (1998). Methodological challenges in evaluating business incubator outcomes. Economic Development Quarterly, 12(4), 313-321.

Storey, D. J., \& Strange, A. (1992). Entrepreneurship in Cleveland 1979-1989: A study of the effects of the enterprise culture (No. 3). Sheffield: Employment Department..

Woodside, A. G. (2013). Moving beyond multiple regression analysis to algorithms: Calling for adoption of a paradigm shift from symmetric to asymmetric thinking in data analysis and crafting theory. Journal of Business Research, 66(4), 463-472. 
Table 2. Outcome and conditions-description and codifications

\begin{tabular}{|c|c|c|}
\hline $\begin{array}{l}\text { Outcome } \\
\text { Conditions }\end{array}$ & Description & Codification \\
\hline $\begin{array}{l}\text { Outcome: } \\
\text { Surviv }\end{array}$ & $\begin{array}{l}\text { Dichotomous variable indicating firm } \\
\text { survival for the period 2009-2014 }\end{array}$ & $\begin{array}{l}\text { Survived } 1 \\
\text { Did not survive } 0\end{array}$ \\
\hline Size & $\begin{array}{l}\text { Continuous variable that specifies the } \\
\text { number of employees }\end{array}$ & Fuzzy variable \\
\hline Export & $\begin{array}{l}\text { Dichotomous variable that shows } \\
\text { whether a firm exports goods or services }\end{array}$ & $\begin{array}{l}\text { Exports } 1 \\
\text { Does not export } 0\end{array}$ \\
\hline EBT & $\begin{array}{l}\text { Variable that distinguishes between } \\
\text { technology-based and non-techonlogy } \\
\text { firms }\end{array}$ & $\begin{array}{l}\text { Tech-based: } 1 \\
\text { Not tech-based: } 0\end{array}$ \\
\hline EBIC & $\begin{array}{l}\text { Variable that reflects the interaction } \\
\text { between firms and the EBIC }\end{array}$ & $\begin{array}{l}\text { Use of the EBIC } 1 \\
\text { Does not use the EBIC } 0\end{array}$ \\
\hline Sector & $\begin{array}{l}\text { Dichotomous variable distinguishing } \\
\text { between the service sector and the } \\
\text { product sector }\end{array}$ & $\begin{array}{l}\text { Product sector } 1 \\
\text { Service sector } 0\end{array}$ \\
\hline
\end{tabular}


Table 3. Analysis of necessary conditions

\begin{tabular}{lcc}
\hline $\begin{array}{l}\text { Analysis of Necessary Conditions } \\
\text { Outcome variable: Surviv }\end{array}$ & \\
\hline & Consistency & Coverage \\
\hline size & 0.739000 & 0.827857 \\
export & 0.400000 & 0.666667 \\
ebt & 0.333333 & 0.625000 \\
ebic & 0.466667 & 0.666667 \\
sector & 0.633333 & 0.655172 \\
\hline
\end{tabular}


Table 4. Results of the intermediate solution (dependent variable: survival)

\begin{tabular}{lccc}
\hline \multicolumn{1}{c}{ Causal Configuration } & $\begin{array}{c}\text { Raw } \\
\text { coverage }\end{array}$ & $\begin{array}{c}\text { Unique } \\
\text { Coverage }\end{array}$ & Consistency \\
\hline size*ebt & 0.243667 & 0.135667 & 0.949351 \\
size*sector & 0.484333 & 0.204000 & 0.809471 \\
size*ebic & 0.331333 & 0.079000 & 0.901996 \\
$\sim$ ebt*sector*ebic & 0.266667 & 0.054333 & 0.800000 \\
& & & \\
solution coverage: 0.793333 & & & \\
solution consistency: 0.824385 & & & \\
\hline
\end{tabular}


Table 5. . Results of the intermediate solution (dependent variable: non survival)

\begin{tabular}{lccc}
\hline \multicolumn{1}{c}{ Causal Configuration } & $\begin{array}{c}\text { Raw } \\
\text { coverage }\end{array}$ & $\begin{array}{c}\text { Unique } \\
\text { Coverage }\end{array}$ & Consistency \\
\hline$\sim$ size* $^{*} \sim$ export* ${ }^{*}$ ebic & 0.328235 & 0.165882 & 0.645087 \\
$\sim$ size*sector* $\sim$ ebic $^{*}$ size*ebt*sector & 0.202941 & 0.040588 & 0.548490 \\
$\sim$ size* $^{*}$ ebt* sector* export $^{*}$ size* ebt* $\sim$ sector* ebic & 0.164118 & 0.110000 & 0.744000 \\
& 0.164118 & 0.164118 & 0.651869 \\
solution coverage: 0.690000 & 0.047059 & 0.047059 & 1.000000 \\
solution consistency: 0.698630 & & & \\
\hline
\end{tabular}

